\title{
Perbandingan Fitur Smartphone, Pemanfaatan dan Tingkat Usability Pada Android dan iOS Platforms
}

\author{
Sasa Ani Arnomo, Hendra \\ Universitas Putera Batam, Jl. R. Soeprapto, Batam, Indonesia
}

\section{KEYWORDS}

Android, iOS, Features, Utilizations, Usability.

\section{CORRESPONDENCE}

E-mail: sasa@puterabatam.ac.id

\section{PENDAHULUAN}

Smartphone atau ponsel pintar telah menjadi bagian penting dalam kehidupan manusia dimana tidak hanya digunakan sebagai alat komunikasi saja tetapi juga bermanfaat dalam memenuhi kebutuhan manusia yang lain seperti dalam hal entertainment atau hiburan, tracking, dan lain-lain. Fungsinya yang telah melampaui tidak hanya sebatas alat komunikasi tersebut, telah mendapatkan pernyataan baru bahwa smartphone adalah alat yang multi-fungsi seperti komputer. Smartphone adalah ponsel yang dibuat berdasarkan sistem operasi dengan kemampuan komputasi dan konektivitas yang lebih maju daripada telepon [1]. Secara sederhananya dapat disimpulkan bahwa smartphone juga memiliki sistem operasi yang bekerja dalam menyelesaikan atau memenuhi permintaan fungsi dan perintah yang dimintakan oleh pengguna (user).

Sistem operasi Smartphone yang sering dijumpai dan dibahas di pasar smartphone pada umumnya berupa Android, iOS, Windows Mobile, Symbian, Blackberry, dan lain-lain. Saat ini, Android dan iOS adalah sistem operasi yang paling banyak atau mendominasi di pasar smartphone. Smartphone yang masuk di Indonesia mengalami kenaikan sebesar 22\% dan mencapai 9,4 juta unit pada kuartal 2 di tahun 2018. Berikut perbandingan penjualan smartphone tahun 2017 dan tahun 2018:

\section{A B $\mathbf{S}$ T $\mathbf{R}$ A $\mathbf{C}$ T}

Android dan iOS nowadays have become the most dominating operating system in technology as well as the number of devices that exist in the world. However, consumers are aspects. So, this research is being conducted with the purpose to learn about the comparison of these two operating system in terms of features, utilizations and usability. Method that is being used in this research is descriptive analysis which in comparison of features and usability comparison is using questionnaire technique. Result of the research has shown that and Smart Caller ID with Facetime. Afterwards, comparison of utilizations has shown that Android is mostly being used for communication as for iOS more for information searching. Meanwhile, for descriptive result of usability has shown that Android and iOS have the same evel of ease of use which is good.

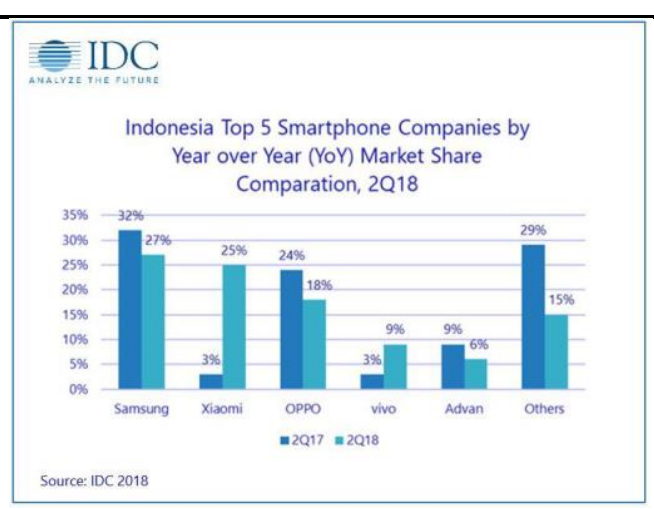

Gambar 1. Perbandingan Penjualan Smartphone

Salah satu jenis sistem operasi smartphone yang diperbandingkan dalam penelitian ini adalah Android, merupakan suatu sistem operasi yang berbasis Linux untuk smartphone ataupun pada komputer tablet [2]. Android menyediakan platform terbuka bagi para pengembang dalam menciptakan aplikasi mereka sendiri untuk digunakan oleh bermacam peranti penggerak. Smartphone pertama yang menggunakan Android adalah HTC Dream, yang dirilis pada tahun 2008. Jenis sistem operasi smartphone kedua adalah iOS, merupakan sistem operasi yang dikembangkan dan didistribusikan oleh Apple Inc [3] yang diluncurkan pada tahun 2007 untuk iPhone dan iPod Touch, dan telah dikembangkan untuk mendukung perangkat Apple lainnya seperti iPad dan 
Apple TV. Apple tidak melisensikan iOS untuk dipasang di perangkat keras non-Apple atau dengan kata lain hanya khusus untuk produk Apple sendiri.

Android memiliki pesaing utama yaitu iOS dan sebaliknya juga untuk iOS. Pesatnya pertumbuhan kedua sistem operasi tersebut menjadi harapan yang ditunggu-tunggu bagi para peminat smartphone sehingga kedua sistem operasi terus berkembang pesat dari segi teknologi maupun dari jumlah device yang ada di dunia. Sebenarnya smartphone berbasis Android dan iOS memiliki kekurangan dan kelebihan masing-masing sehingga banyak pengguna smartphone mengalami kesulitan untuk memilih 2 smartphone yang sesuai dengan kebutuhan dan keinginan. Faktor yang mengakibatkan kurang mengertinya smartphone berbasis Android dan iOS adalah pengguna tidak mengetahui sebenarnya apa perbedaan dari kedua sistem operasi tersebut sehingga membuat para pengguna tidak dapat memilih smartphone yang sesuai dengan keinginannya. Para pengguna juga masih kurang mengerti cara penggunaan dari kedua sistem operasi dari berbagai segi seperti fitur-fitur, pemanfaatan, kemudahan penggunaan dan lain-lain. Perbadingan fisiologis dan psikologis pengguna tentang perilaku menggunakan ponsel dan kemampuan operasi telah diteliti [4] tetapi perbandingan fitur belum dilakukan perbedaanya begitu juga ditinjau dari segi keamanan[5]. Fitur smartphone sebagai indicator perbandingan adalah interface telp, interface pesan, memo, multitasking, voice command, notifikasi, dan sinkronisasi.

Tujuan dari penelitian ini adalah sebagai berikut: (1) Untuk mengetahui perbandingan penggunaan smartphone berdasarkan fitur-fitur pada versi Android 4.4 (Kitkat) dan iOS 8; (2) Untuk mengetahui perbandingan penggunaan smartphone berdasarkan fitur-fitur pada versi Android 5.0 (Lollipop) dan iOS 9; (3) Untuk mengetahui perbandingan pemanfaatan penggunaan smartphone berbasis Android dan iOS; (4) Untuk mengetahui perbandingan usability (kemudahan penggunaan) dalam penggunaan smartphonei berbasis Android dan iOS.

\section{TINJAUAN PUSTAKA DAN METODELOGI}

\section{Sistem Operasi Smartphone}

Apple App Store dan Google Play Store berhasil menaklukkan perangkat seluler. Namun, keberhasilan ini juga menantang pengembang aplikasi untuk menerbitkan aplikasi berkualitas tinggi agar tetap menarik dan memuaskan pengguna[6]. Smartphone dapat dibedakan menjadi dua kategori umum yaitu: Berdasarkan manufaktur, Terdapat banyak macam smartphone yang diproduksi oleh sebagian besar manufaktur seperti, Apple, Samsung, HTC, LG, Nokia, Blackberry, Sony, Motorola, dan lain-lain; (2) Berdasarkan sistem operasi smartphone, Ada 3 sistem operasi utama pada smartphone: Google Android adalah sistem operasi yang paling populer pada smartphone, dan terdapat ratusan model smartphone dari puluhan produsen yang menggunakannya., Apple iOS, sistem yang digunakan pada iPhone dan iPad adalah sistem yang sederhana. Pengguna hanya menyentuh sebuah ikon untuk meluncurkan fitur smartphone tertentu atau aplikasi dan Windows phone buatan Microsoft dan dengan antarmuka seperti Windows 8. Menyentuh salah satu blok layar dijalankan aplikasi dan fitur smartphone yang berbeda-beda. Dari keduanya sudah mendukung 4G/LTE [7]. Ditinjau dari layout mapping [8] maka Aplikasi Android ini terdiri dari dua activities yaitu layar awal dan layar detail. Setiap activity mempunyai jendela untuk menggambarkan kontrol antarmuka yang berfungsi untuk berinteraksi dengan pengguna. layar beranda berisi tombol untuk menampilakan tugas dan tampilan daftar untuk menampilkan tugas yang ditambahkan. Layar detail menunjukkan informasi untuk tugas tertentu dari pengguna. Pada iphone IOS mempunyai sistem operasi yang lebih sempurna dan kompetibel terutama untuk pengembangan aplikasi permainan [9].

\section{Fitur Smartphone}

Fitur-fitur merupakan alat bersaing untuk membedakan produk suatu perusahaan terhadap produk perusahaan lain yang digunakan untuk sebagai sarana untuk membedakan suatu merk dari pesaingnya (Bahiu, 2015). Beberapa fitur-fitur pada smartphone menurut Supardi (2012: 85) yaitu: (1) Fitur menelepon, menelepon merupakan kata kerja dari telepon yang berarti pesawat dengan listrik dan kawat, untuk bercakap-cakap antara dua orang yang berjauhan termpatnya atau bercakapcakap melalui pesawat telepon; (2) Fitur pesan atau SMS (Short Messsage Service), sebuah layanan yang dilaksanakan dengan sebuah ponsel atau smartphone untuk mengirim atau menerima pesan-pesan pendek; (3) Fitur memo, fitur untuk melakukan catatan penting; (4) Multitasking, melakukan tugas secara serentak atau sekaligus pada aplikasi yang sama maupun berbeda; (5) Voice Command, merupakan suatu pengembangan teknik dan sistem yang memungkinan smartphone untuk menerima masukan berupa kata-kata yang diucapkan pengguna; (6) Notifikasi, pemberitahuan atau kabar tentang suatu. Seperti notifikasi pesan, notifikasi aplikasi, dan lain-lain; (7) Sinkronisasi, kumpulan data yang identik berada dalam suatu atau beberapa lokasi yang sama.

\section{Pemanfaatan Penggunaan Smartphone}

Menurut penelitian Wulandari, dkk (2014) bahwa pemanfaatan penggunaan smartphone dapat dibagi dalam beberapa segi, yakni: (1) Komunikasi yaitu penggunaan smartphone sebagai alat komunikasi berarti pengiriman dan penerimaan pesan atau berita antara 2 orang atau lebih sehingga pesan yang dimaksud dapat dipahami; (2) Informasi yaitu penggunaan smartphone dalam mancari informasi (fakta); (3) Pergaulan yaitu penggunaan smartphone sebagai perihal bergaul atau berkehidupan masyarakat; (4) Cari Jodoh yaitu penggunaan smartphone dalam mencari pasangan; (5) Akademik yaitu penggunaan smartphone sebagai alat bantu dalam akademi atau bersifat ilmiah dan pengetahuan; (6) Hiburan yaitu penggunaan smartphone sebagai alat untuk mencari kehiburan atau bersifat menghiburkan; (7) Bisnis Online yaitu penggunaan smartphone sebagai alat mencari keuntungan dengan menggunakan internet;

\section{Usability Smartphone}

Usability mengacu kepada bagaimana pengguna bisa mempelajari dan menggunakan produk untuk memperoleh tujuannya dan seberapa puaskah mereka terhadap penggunaannya [10]. Berdasarkan definisi tersebut usability diukur berdasarkan indikator-indikator berikut:

Tabel 1. Indikator Usability

\begin{tabular}{lll} 
Indikator & Keterangan & \\
\hline Kemudahan & didefinisikan & seberapa cepat pengguna \\
(Learnability) & mahir dalam menggunakan sistem serta
\end{tabular}


kemudahan dalam penggunaan menjalankan suatu fungsi serta apa yang pengguna inginkan dapat mereka dapatkan.

Effisiensi didefinisikan sebagai sumber daya yang (Efficiency) dikeluarkan guna mencapai ketepatan dan kelengkapan tujuan.

Mudah Diingat didefinisikan bagaimana kemampuan (Memorability) pengguna mempertahankan pengetahuannya setelah jangka waktu tertentu, kemampuan mengingat mendapatkan didapatkan dari peletakkan menu yang selalu tetap.

Kesalahan didefinisikan berapa banyak kesalahan(Errors) kesalahan apa saja yang dibuat pengguna, kesalahan yang dibuat pengguna mengcakup ketidaksesuaian apa yang pengguna pikirkan dengan apa yang sebenarnya disajikan oleh sistem.

Kepuasan didefiniskan kebebasan dari

(Satisfaction) ketidaknyamanan, dan sikap positif terhadap penggunaan produk atau ukuran subjektif sebagaimana pengguna merasa tentang penggunaan sistem.

\section{Indikator Mapping Perbandingan}

Analisis komparatif pada penelitian ini yaitu membandingkan penggunaan smartphone berbasis Android dan iOS. Indikator perbandingan yang digunakan sesuai pada tabel berikut:

Tabel 2. Indikator mapping

\begin{tabular}{|c|c|}
\hline Perbandingan & Indikator \\
\hline \multirow{7}{*}{$\begin{array}{l}\text { Fitur-Fitur Android } 4.4 \\
\text { (Kitkat) dan iOS } 8 \\
\text { Fitur-Fitur Android } 5.0 \\
\text { (Lollipop) dan iOS } 9\end{array}$} & Interface Menelepon \\
\hline & Interface Pesan \\
\hline & Memo \\
\hline & Multitasking \\
\hline & Voice Command \\
\hline & Notifikasi \\
\hline & Sinkronisasi \\
\hline \multirow{7}{*}{ Pemanfaatan } & Komunikasi \\
\hline & Akademik \\
\hline & Informasi \\
\hline & Hiburan \\
\hline & Pergaulan \\
\hline & Bisnis Online \\
\hline & Cari Jodoh \\
\hline \multirow{5}{*}{ Usability } & Learnability \\
\hline & Efficiency \\
\hline & Memorability \\
\hline & Errors \\
\hline & Satisfaction \\
\hline
\end{tabular}

\section{Interpretasi Skor Perhitungan}

Skala Likert merupakan metode skala bipolar yang mengukur baik tanggapan positif ataupun negatif terhadap suatu pernyataan. Skala Likert mempunyai reliabilitas yang relatif tinggi dibandingkan dengan skala lainnya. Skor tingkat penggunaan diambil dari rumus sebagai berikut:

Total skor: T x Pn

$\mathrm{T}=$ Total jumlah responden yang memilih

Pn $=$ Pilihan angka skor Likert

Sedangkan untuk melihat interpretasi skor yang menunjukan berapa persen nilai dari indikator tersebut menggunkan persamaan sebagai berikut:

Rumus Index \% = Total Skor $/$ Y x 100

Dimana $\mathrm{Y}=$ skor tertinggi likert $\mathrm{x}$ jumlah responden

\section{HASIL DAN PEMBAHASAN}

Dalam penelitian, terdapat 2 objek penelitian yaitu smartphone berbasis Android dan iOS. Berikut adalah tabel profil antara Android dan Ios.

Tabel 3. Profil Objek Penelitian

\begin{tabular}{|c|c|c|}
\hline Profil & Android & $\mathrm{iOS}$ \\
\hline $\begin{array}{c}\text { Perusahaan/Pengemb } \\
\text { ang }\end{array}$ & Google & Apple Inc. \\
\hline Diprogram dalam & $\mathrm{C}, \mathrm{C}++$, Java & $\begin{array}{c}\mathrm{C}, \mathrm{C}++, \\
\text { Objectives-C }\end{array}$ \\
\hline Model Sumber & Sumber Terbuka & Sumber Tertutup \\
\hline Rilis Perdana & 23 September 2008 & 29 Juni 2007 \\
\hline Ketersediaan Bahasa & 70 Bahasa & 34 Bahasa \\
\hline \multirow[t]{2}{*}{ Lisensi } & $\begin{array}{c}\text { Lisensi Apache } 2.0 \\
\text { GNU } \\
\text { GPL } v 2 \text { untuk } \\
\text { modifikasi }\end{array}$ & $\begin{array}{c}\text { Proprietary } \\
\text { EULA } \\
\text { kecuali pada } \\
\text { komponen } \\
\end{array}$ \\
\hline & Kernel Linux & sumber terbuka \\
\hline Situs Web Resmi & www.android.com & www.apple.com \\
\hline
\end{tabular}

Perbandingan Fitur-Fitur Penggunaan Smartphone Berbasis Android 4.4 (Kitkat) dan iOS 8

Berdasarkan observasi yang dilakukan peneliti di Kampus Universitas Putera Batam, peneliti mengobservasi dengan para pengguna smartphone berbasis Android seperti pada smartphone XiaoMi, Samsung, Sony Xperia, Oppo, dan Advan yang berbasis Android 4.4 (Kitkat) serta pengguna smartphone iOS seperti iPhone 4G, 4S, 5G, dan 5S yang masih berbasis iOS 8 .

Data yang diperoleh pengguna kemudian didukung oleh dokumentasi seperti artikel pada website resmi Android yaitu www.android.com dan website resmi iOS yaitu www.apple.com. Serta dukungan buku Masruri (2015: 17) mengenai fitur-fitur Android 4.4 (Kitkat). Berikut tabel deskriptif perbandingan fitur-fitur penggunaan smartphone berbasis Android dan iOS pada halaman berikutnya. 
Tabel 4. Deskriptif Perbandingan Fitur-Fitur Penggunaan Smartphone Berbasis Android 4.4 (Kitkat) dan iOS 8

\begin{tabular}{ll}
\hline Menelepon & \multicolumn{2}{c}{ Android 4. } \\
\hline & $\begin{array}{l}\text { Fitur Smart Caller } \\
\text { menyesuaikan nomo } \\
\text { mengenali kontak yan } \\
\text { sehingga secara otom } \\
\text { menarik kontak ala } \\
\text { kontak dari database }\end{array}$ \\
& \\
&
\end{tabular}

Gambar 2. Fitur Smart Caller ID Kitkat

Fitur kontak prioritas yaitu secara otomatis sistem akan mengurutkan daftar dalam kontak sesuai dengan prioritas berdasarkan keseringan nomor kontak tersebut di hubungi

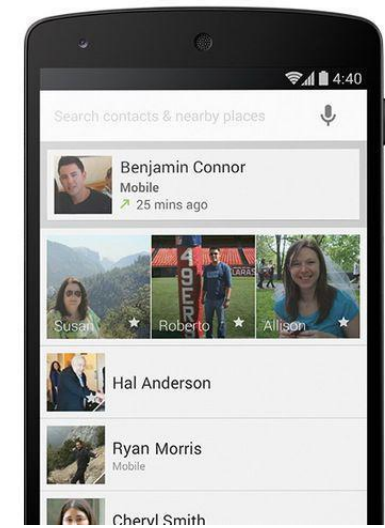

Gambar 4. Kontak Prioritas pada Kitkat

\begin{tabular}{ll}
\hline Menelepon & iOS 8 \\
\hline & Fitur Facetime yaitu fitur yang \\
& diberikan Apple untuk melakukan \\
& panggilan secara video maupun \\
& audiovsaja ke semua pengguna iDevice \\
& atauvdengan kata lain hanya produk Apple \\
& seperti iPhone, iPad dan Mac dengan \\
& menggunakan jaringan Wi-fi.
\end{tabular}

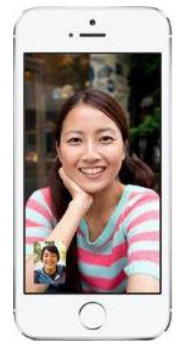

Gambar 3. Fitur Facetime Video iOS 8
Google Hangouts mendukung mengirim dan menerima pesan serta video dan audio antar pengguna Hangouts.

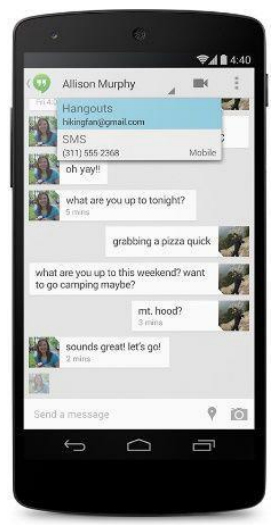

Gambar 5. Google Hangouts Kitkat iOS 8

\begin{tabular}{ll}
\hline Pesan & iOS 8 \\
iMessage yaitu fitur yang diberikan Apple \\
untukengirim pesan serta video atau \\
audo dengan menggunakan jaringan Wi-fi \\
dan seluler antar pengguna iDevice.
\end{tabular}


Italic, dan Underline.

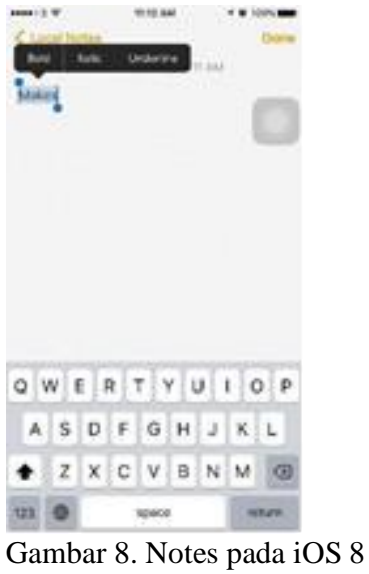

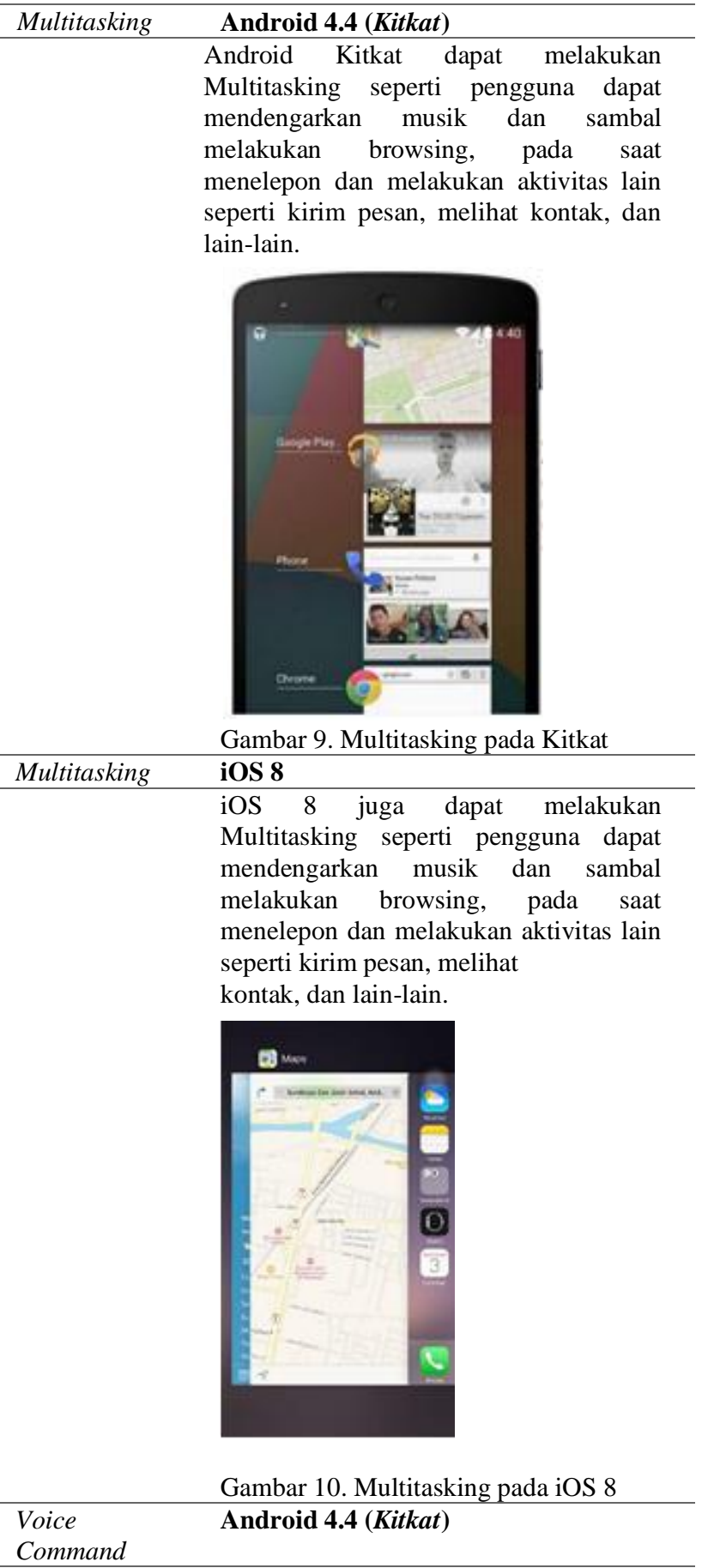

Fitur "OK Google" hanya dengan mengatakan "OK Google" untuk mengaktifkan fitur asisten pribadi

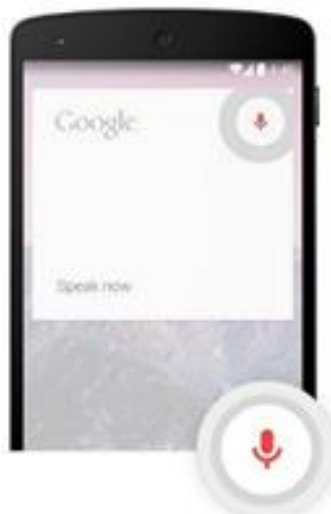

Gambar 11. OK Google pada Kitkat

\begin{tabular}{ll}
$\begin{array}{l}\text { Voice } \\
\text { Command }\end{array}$ & iOS 8 \\
\hline
\end{tabular}

Fitur Siri pada iOS yang memungkinkan aktivasi hanya dengan menyebut "Hey, Siri" dan juga dapat mendeteksi lagu yang sedang diputar.

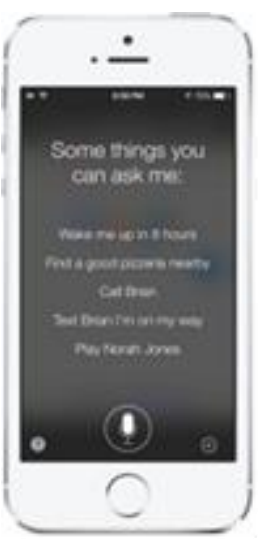

Gambar 12. Siri pada iOS 8

\begin{tabular}{lll} 
Notifikasi & \multicolumn{3}{l}{ Android 4.4 (Kitkat) } & \\
& Notifikasi pada Android & Kitkat \\
menyediakan beberapa pilihan & seperti \\
menghidupkan/mematikan Wi-fi, & senter, \\
& silent, Bluetooth, mobile data, dan lainlain \\
& sesuai kebutuhan pengguna.
\end{tabular}

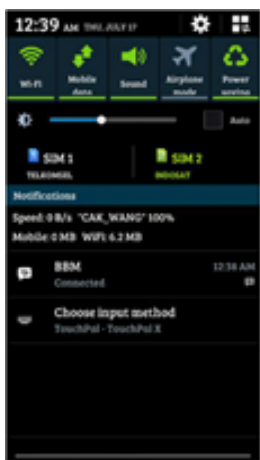

Gambar 13. Notifikasi pada Kitkat 


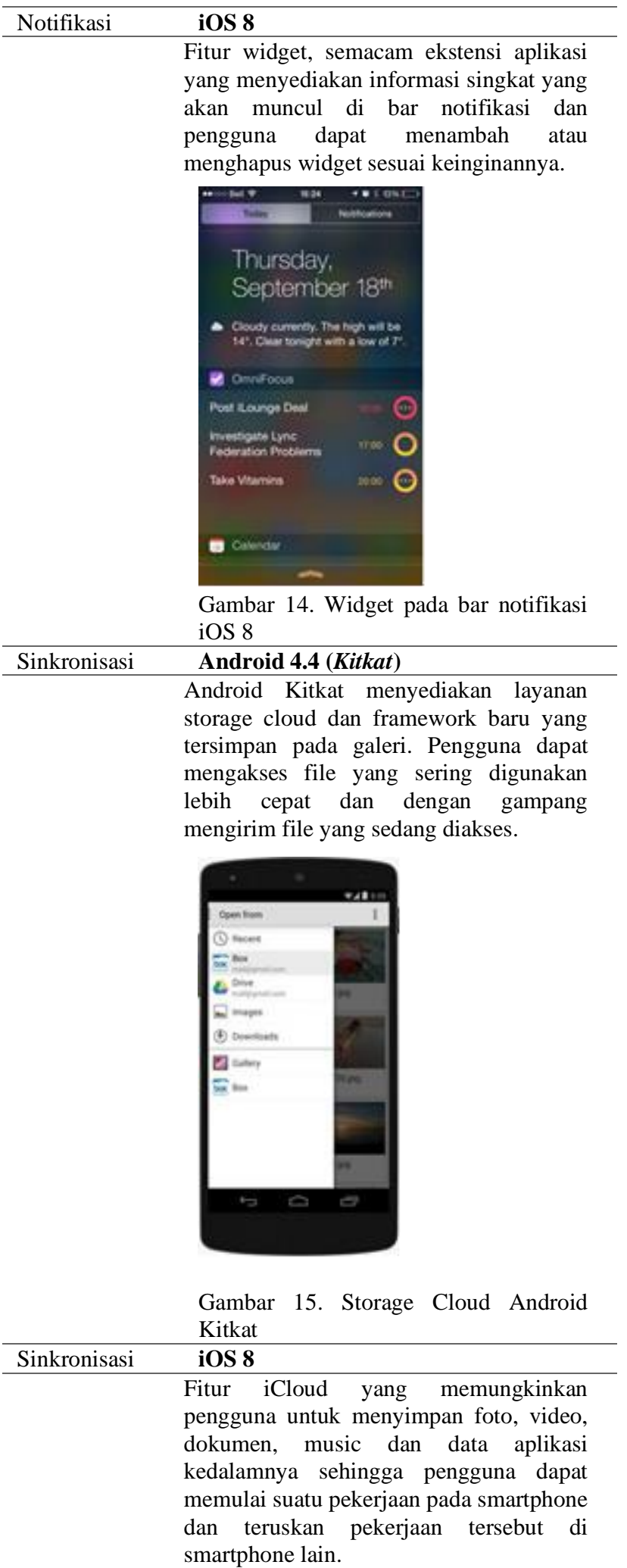

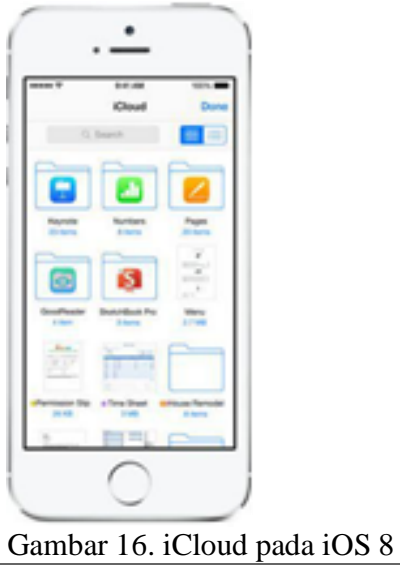

Perbandingan Fitur-Fitur Penggunaan Smartphone Berbasis Android 5.0 (Lollipop) dan iOS 9

Berdasarkan observasi yang dilakukan peneliti di Kampus Universitas Putera Batam, peneliti mengobservasi dengan para pengguna smartphone berbasis Android seperti pada smartphone XiaoMi, Samsung, Sony Xperia, Oppo, dan Advan yang berbasis Android 5.0 (Lollipop) serta pengguna smartphone iOS seperti iPhone 6G dan 6S yang masih berbasis iOS 9.

Data yang diperoleh pengguna kemudia didukung oleh dokumentasi seperti artikel pada website resmi Android yaitu www.android.com dan website resmi iOS yaitu www.apple.com. Serta dukungan buku Masruri (2015: 20) mengenai fitur-fitur Android 5.0 (Lollipop).

Tabel 5. Perbandingan Fitur-Fitur Penggunaan Smartphone Berbasis Android 5.0 (Lollipop) dan iOS 9

\begin{tabular}{ll}
\hline Menelepon & Android 5.0 (Lollipop) \\
\hline & Google Hangouts telah mendukung \\
& melalukan panggilan yang berarti \\
& pengguna lebih gampang dalam \\
& penggunaan aplikasi untuk melakukan \\
& panggilan dan pengiriman pesan. \\
\hline Menelepon & iOS 9 \\
\hline & Fitur Facetime mendukung pemanggilan \\
& video dan audio dengan jaringan Wi-fi \\
& maupun seluler. \\
\hline Pesan & Android 5.0 (Lollipop) \\
\hline & Google Hangouts pada Lollipop \\
& memiliki antarmuka yang lebih bagus \\
dengan konsep Material dan dukungan & grup chat.
\end{tabular}

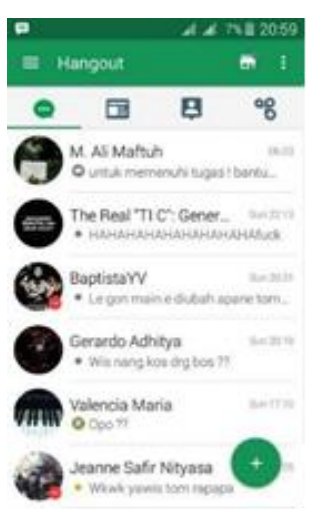

Gambar 17. Google Hangouts pada 


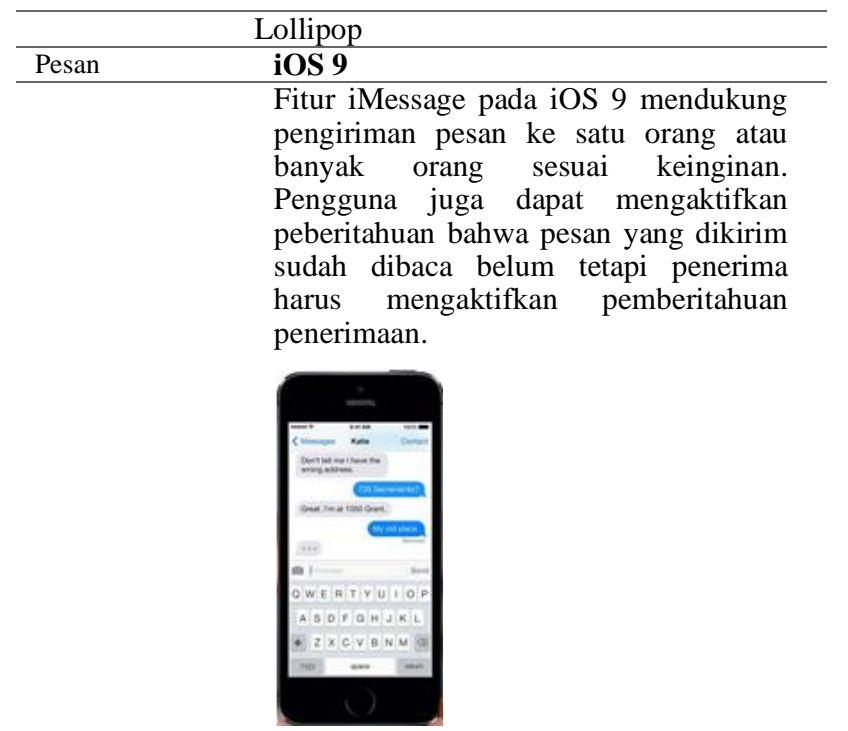

Gambar 18. iMessage pada iOS 9

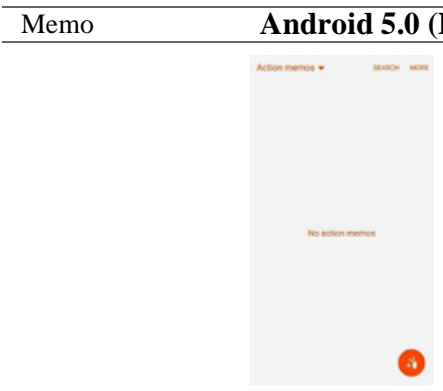

Tidak terjadi perubahan fitur tambahan pada aplikasi memo tetapi ada perubahan pada tampilan memo pada lolipop.

Gambar 19. Memo pada Lollipop iOS 9

Fitur Notes yang lebih canggih dan hadir dengan fitur yang lengkap seperti checklist, menggambar, menyisipkan foto dan dukungan sinkronisasi antar perangkat melalui iCloud.

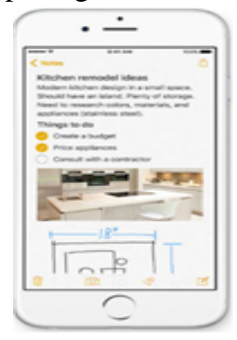

Gambar 20. Notes pada iOS 9

\begin{tabular}{|c|c|}
\hline Multitasking & Android 5.0 (Lollipop) \\
\hline & $\begin{array}{l}\text { Tidak terjadi perubahan mendasar dan } \\
\text { masih dalam proses pengembangan oleh } \\
\text { Google. }\end{array}$ \\
\hline \multirow[t]{2}{*}{ Multitasking } & iOS 9 \\
\hline & $\begin{array}{l}\text { Multitasking pada iOS } 9 \text { mendukung } \\
\text { melakukan } 2 \text { aktivitas secara bersamaan } \\
\text { akan tetapi hanya mendukung perangkat } \\
\text { iPad. }\end{array}$ \\
\hline \multirow{3}{*}{$\begin{array}{l}\text { Voice } \\
\text { Command }\end{array}$} & Android 5.0 (Lollipop) \\
\hline & \\
\hline & $\begin{array}{l}\text { Fitur } O K \text { Google ditingkatkan dalam } \\
\text { mengakses informasi dan untuk } \\
\text { mendapatkan jawaban cepat, mengirim } \\
\text { pesan teks, dan mendapatkan petunjuk } \\
\text { yang lebih banyak. }\end{array}$ \\
\hline
\end{tabular}

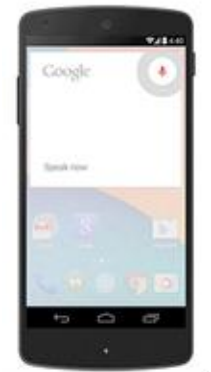

Gambar 21. OK Google pada Lollipop

\begin{tabular}{ll}
$\begin{array}{l}\text { Voice } \\
\text { Command }\end{array}$ & iOS 9 \\
\hline
\end{tabular}

Fitur Siri pada iOS 9 ditingkatkan kinerjanya dan mendukung pencarian menggunakan bahasa yang lebih alami. Pengembang mendapatkan akses ke Siri, berarti para pengembang dapat menemukan cara kreatif untuk memanfaatkan Siri ke dalam aplikasi mereka.

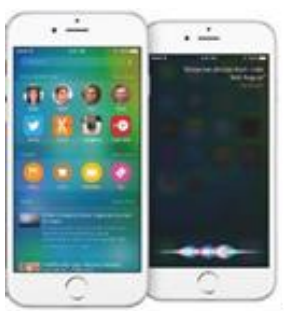

Gambar 22. Siri pada iOS 9

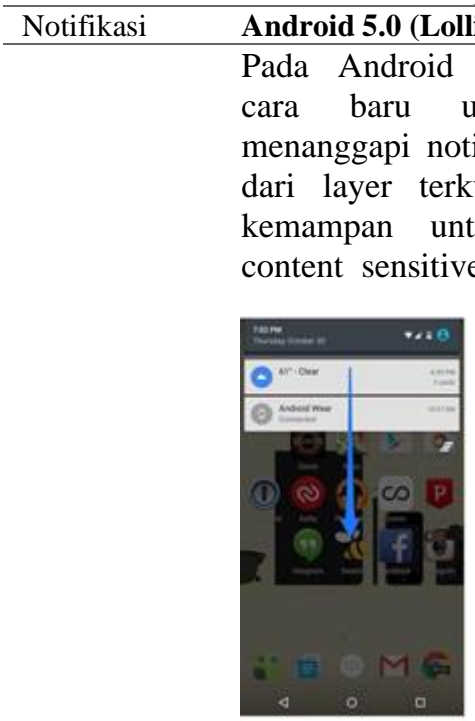

pesan.

Gambar 23. Notifikasi pada Lollipop

Notifikasi iOS 9

Pada iOS 9 mendukung fitur baru untuk menerima tampilan notifikasi bukan dalam bentuk grup dan sesuai urutan kronologis dan pengguna masih bisa mengatur untuk menerima notifikasi dalam bentuk grup atau bukan grup. 


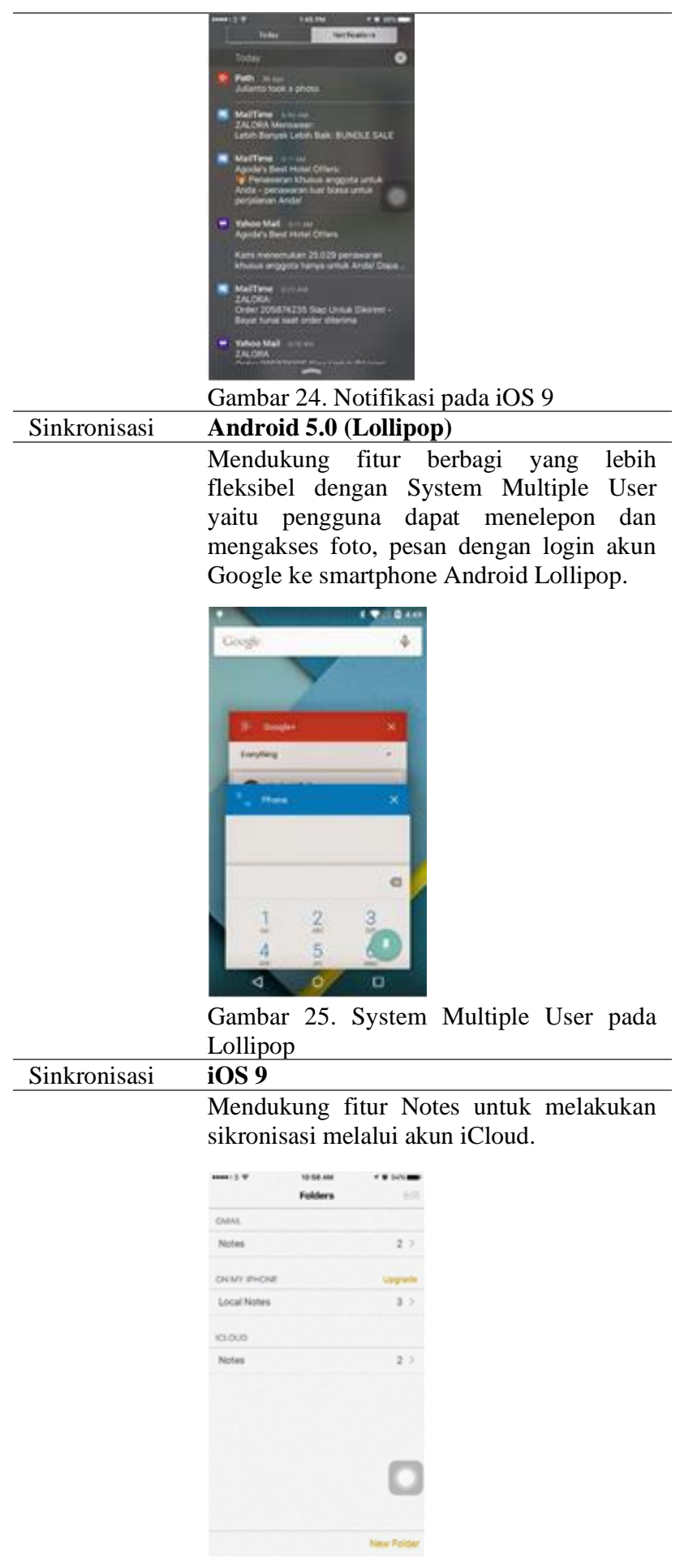

Gambar 26. Sinkronisasi Notes pada Ios

\section{Deskriptif Persepsi Pemanfaatan Penggunaan Smartphone Berbasis Android dan iOS}

Hasil jawaban dari kuesioner untuk pemanfaatan penggunaan smartphone Android dan iOS seperti tabel pada halaman berikutnya.

Tabel 6. Persepsi Pemanfaatan Penggunaan Smartphone Berbasis Android dan iOS

\begin{tabular}{ccc}
\hline \multirow{3}{*}{ Indikator } & Android & iOS \\
\cline { 2 - 3 } & Persen (\%) & Persen (\%) \\
\hline
\end{tabular}

DOI: https://doi.org/10.30743/infotekjar.v3i2.1002

\begin{tabular}{lcc}
\hline Komunikasi & 93,33 & 83,33 \\
\hline Informasi & 66,67 & 88,33 \\
\hline Pergaulan & 58,33 & 56,67 \\
\hline Cari Jodoh & 15,00 & 13,33 \\
\hline Akademik & 61,67 & 76,67 \\
\hline Hiburan & 45,00 & 73,33 \\
\hline Bisnis Online & 18,33 & 6,67 \\
\hline
\end{tabular}

Berdasarkan tabel 6 di atas, ternyata dari 60 para pengguna smartphone Android dan iOS. Nilai tertinggi yang terpilih pada Android adalah untuk Komunikasi sejumlah 93,33\% dari jumlah pengguna dan pada iOS adalah untuk pencarian Informasi sejumlah $88,33 \%$ dari jumlah pengguna. Nilai terendah pada Android adalah karena Dibelikan Orangtua sejumlah 11,67\% dari jumlah pengguna dan pada iOS adalah untuk melakukan Bisnis Online sejumlah 6,67\% dari jumlah pengguna. Berikut grafik pemanfaatan penggunaan smartphone berbasis Android dan iOS.

\section{Persepsi Tingkat Usability Penggunaan Smartphone Berbasis Android dan iOS}

Berdasarkan analisis deskriptif persepsi tingkat usability penggunaan smartphone berbasis Android dan iOS yang sudah diuraikan. Berikut tabel perbandingan persepsi tingkat usability penggunaan smartphone Android dan iOS.

Tabel 10. Perbandingan Persepsi Tingkat Usability Penggunaan Smartphone Berbasis Android dan iOS

\begin{tabular}{clcc}
\hline No. & Indikator & Android & iOS \\
\cline { 3 - 4 } & & Skor & Skor \\
\hline 1. & Learnability & 236 & 203 \\
\hline 2. & Efficiency & 213 & 227 \\
\hline 3. & Memorability & 235 & 215 \\
\hline 4. & Errors & 190 & 242 \\
\hline 5. & Satisfaction & 214 & 232 \\
\hline & Skor Total & 1088 & 1119 \\
\hline & Skor Rata-Rata & 217,6 & 223,8 \\
\hline
\end{tabular}

Dari hasil uraian di atas, dapat dilihat bahwa nilai tertinggi adalah skor 242 pada indikator Errors iOS dan terendah adalah skor 190 pada indikator Errors Android. Tingkat rata-rata pada Android dan iOS berada pada rentang skala yang sama, 205-252 yaitu Baik. Akan tetapi iOS memiliki skor rata-rata yang lebih tinggi yaitu 223,8 dibanding dengan Android yaitu 217,6.

\section{KESIMPULAN}

Berdasarkan hasil penelitian dan pembahasan sebelumnya, maka dapat disimpulkan bahwa: (1) Perbandingan penggunaan smartphone berdasarkan fitur-fitur pada versi Android 4.4 (Kitkat) dan iOS 8, yakni Android 4.4 (Kitkat) memiliki fitur smart caller ID, kontak prioritas, Google hangouts, pembuatan checklist, multitasking, "OK Google", menghidupkan atau mematikan beberapa pilihan pada notifikasi (seperti Wi-Fi, senter, silent, bluetooth dan lain-lain), layanan storage cloud dan framework sedangkan pada iOS 8 mendukung Facetime, iMessage, format task standard seperti bold, italic dan underline, multitasking, Siri, widget dan iCloud; (2) Perbandingan 
penggunaan smartphone berdasarkan fitur-fitur pada versi Android 5.0 (Lollipop) dan iOS 9, yakni Android 5.0 (Lollipop) memiliki fitur pemanggilan melalui Google hangouts, tampilan Google hangouts yang lebih bagus, tampilan memo yang lebih bagus, multitasking, fitur "OK Google"yang ditingkatkan dalam mengakses informasi, cara baru melihat dan menanggapi notifikasi dengan layar terkunci, dan System Multi User sedangkan pada iOS 9 memiliki fitur Facetime melalui jaringan seluler dan Wi-Fi, iMessage yang dapat mengirim pesan ke banyak orang sekaligus, membuat checklist, menggambar dan menyisipkan foto pada Notes, multitasking, Siri yang ditingkatkan kinerjanya, tampilan notifikasi baru dan sinkronisasi Notes melalui iCloud; (3) Perbandingan persepsi pemanfaatan penggunaan smartphone Berbasis Android dan iOS yaitu responden lebih memilih pemanfaatan untuk komunikasi pada smartphone Android yaitu sebesar 93,3\% sedangkan responden lebih memilih pemanfaatan dalam pencarian informasi pada smartphone iOS yaitu sebesar 88,33\%; (4) Perbandingan tingkat usability penggunaan smartphone berbasis Android dengan skor rata-rata sebesar 217,6 dan pada iOS sebesar 223,8 adalah tergolong sama-sama baik.

\section{Ucapan Terima Kasih}

Terima kasih kepada LPPM Universitas Putera Batam sebagai Lembaga yang membantu pengembangan penelitian.

\section{DAFTAR PUSTAKA}

[1] A. Gupta and Nisha, "Architectural Comparison - a Case Study Between Android \& Ios," Int. J. Multidiscip. Consort., vol. 2, no. 2, pp. 6-18, 2015.

[2] O. C. Novac, M. Novac, C. Gordan, T. Berczes, and G. Bujdoso, "Comparative study of Google Android, Apple iOS and Microsoft Windows Phone mobile operating systems," 2017 14th Int. Conf. Eng. Mod. Electr. Syst. EMES 2017, pp. 154-159, 2017.

[3] A. J1, P. Wr, and S. Dm, "The emerging soft tissue paradigm in orthodontic diagnosis and treatment planning .," Clinical Orthodontics and Research, vol. 2, no. 2. pp. 49-52, 1999.

[4] M. Hu, P. Bian, and N. Zhang, "The research of human-machine interactions unity on IOS and android smartphone platform," Proc. 9th Int. Conf. Comput. Sci. Educ. ICCCSE 2014, no. Iccse 2014, pp. 640-643, 2014.

[5] I. Mohamed and D. Patel, "Android vs iOS security: A comparative study," Proc. - 12th Int. Conf. Inf. Technol. New Gener. ITNG 2015, pp. 725-730, 2015.

[6] S. Habchi, G. Hecht, R. Rouvoy, and N. Moha, "Code Smells in iOS Apps: How Do They Compare to Android?," Proc. - 2017 IEEE/ACM 4th Int. Conf. Mob. Softw. Eng. Syst. MOBILESoft 2017, pp. 110 121, 2017.

[7] J. Molina-Gil, P. Caballero-Gil, C. Caballero-Gil, and A. Fúster-Sabater, "Software implementation of the SNOW 3G generator on iOS and android platforms," Log. J. IGPL, vol. 24, no. 1, pp. 29-41, 2014.

[8] X. Fan and K. Wong, "Migrating user interfaces in native mobile applications," Proc. Int. Work. Mob. Softw. Eng. Syst. - MOBILESoft '16, pp. 210-213, 2016.

[9] J. Li and W. Hu, "Development of puzzle game for IOS platform based on Unity3D," Proc. - 3rd Int. Conf.
Appl. Comput. Inf. Technol. 2nd Int. Conf. Comput. Sci. Intell. ACIT-CSI 2015, pp. 468-473, 2015.

[10] D. R. Rahadi, "Pengukuran Usability Sistem Menggunakan Use Questionnaire Pada Aplikasi Android Interface pengguna Android didasarkan pada manipulasi langsung menggunakan masukan sentuh yang serupa dengan tindakan di dunia nyata, seperti menggesek ( swiping ), mengetuk," J. Sist. Inf., vol. 6, no. 1, pp. 661-671, 2014. 